\title{
Anti-GnRH vaccination of stallions shedding equine arteritis virus in their semen: a field study
}

\author{
Fabien Miszczak ${ }^{1,2}$, Dominik Burger ${ }^{3}$, Bénédicte Ferry ${ }^{4}$, Loïc Legrand ${ }^{1,5}$, \\ Guillaume Fortier ${ }^{1,5}$, Anne-Lyse Laine ${ }^{6}$, Astrid Vabret ${ }^{2}$, Stéphane Pronost ${ }^{1,5}$, \\ and Marianne Vidament ${ }^{4,6 *}$ \\ ${ }^{1}$ LABÉO Frank Duncombe (Normandy analysis and research centre) Saint-Contest, France \\ ${ }^{2}$ UNICAEN (Normandy University), Virology service, CHU Caen (Hospital), France \\ ${ }^{3}$ Swiss Institute of Equine Medicine ISME, University of Berne, and Agroscope, Avenches, Switzerland \\ ${ }^{4}$ IFCE (French Institute of Horse and Riding), Saumur, France \\ ${ }^{5}$ Normandie Univ (Normandy University), UNICAEN, BIOTARGEN EA7450, Saint-Contest, France \\ ${ }^{6}$ INRAE, CNRS, Université de Tours (National Research Institute for Agriculture, Food and Environment, National \\ Center for Scientific Research, Tours University), UMR PRC, Nouzilly, France
}

MISZCZAK, F., D. BURGER, B. FERRY, L. LEGRAND, G. FORTIER, A.-L. LAINE, A. VABRET, S. PRONOST, M. VIDAMENT: Anti-GnRH vaccination of stallions shedding equine arteritis virus in their semen: a field study. Vet. arhiv 90, 543-556, 2020.

\section{ABSTRACT}

Stallions are natural reservoirs of equine arteritis virus (EAV) in their semen, representing a potential source of outbreaks. The carrier-state is testosterone-dependent, and clears spontaneously in 4 to $40 \%$ stallions. Reduction of testosterone secretion may be obtained with the anti-GnRH vaccine Equity. In this report, 16 naturally infected stallions excreting EAV in their semen were vaccinated twice with the vaccine Equity ${ }^{\mathrm{TM}}$ and monitored irregularly under field conditions for EAV viral load in their semen and plasmatic testosterone concentration. The results are indicated in months $(\mathrm{M})$ after the first vaccine injection. Testosterone concentrations decreased from 1.7 to $0.2 \mathrm{ng} / \mathrm{mL}$ $(\mathrm{P}<0.002)$ after $3 \mathrm{M}$. The EAV viral load decreased from $3.2 \times 10^{9}$ to $1.1 \times 10^{6} \mathrm{RNA}$ copy $/ \mathrm{mL}$ of semen $(\mathrm{P}<0.001)$ after $5 \mathrm{M}$. One stallion died at 7M for other reason. At M3-10, 12/15 stallions ceased to shed the virus in their semen. At M5$10,9 / 15$ stallions had plasmatic testosterone concentrations of $\geq 0.5 \mathrm{ng} / \mathrm{mL}$ but the 6 others showed a persistently low testosterone concentration $(\leq 0.3 \mathrm{ng} / \mathrm{mL})$. Of the 14 stallions that were expected to recover their reproductive activity at the time of the next breeding season $(<\mathrm{M} 12), 8$ were EAV negative and produced foals, and 6 were not usable (4 for reproductive deficiency and 2 for EAV positivity). All the stallions were EAV negative at M22, with one stallion being vaccinated a third time at M15. These results suggest that the anti-GnRH vaccination could help to clear EAV shedding in stallions, without a significant effect on reproductive capacity for most of them, but some present a long lasting reduced testosterone secretion.

Key words: stallion; equine arteritis virus; anti-GnRH immunization; viral load; testosterone

\footnotetext{
*Corresponding author:

Marianne Vidament, DVM, INRAE, 37380 Nouzilly, France, Phone: +33 2474278 05; E-mail: marianne.vidament@inrae.fr
} 


\section{Introduction}

Stallions are natural reservoirs of equine arteritis virus (EAV), which is the prototype virus of the Arteriviridae family (genus Arterivirus; order Nidovirales) (SNIJDER and MEULENBERG, 1998). Equine arteritis virus is the causative agent of equine viral arteritis (EVA), which represents a reproductive and respiratory disease in horses and other equid species (DOLL et al., 1957; MCCOLLUM and SWERCZEK, 1978; BALASURIYA et al., 2018). Exposure to equine arteritis virus (EAV) usually results in a mild or subclinical infection in immunocompetent horses. Clinical signs of EAV infection may vary in range and severity. Equine arteritis virus is frequently characterized by influenza-like signs in adult horses, but it may also cause abortion in mares, neonatal death, or interstitial pneumonia in young foals (TIMONEY and MCCOLLUM, 1993; MCCOLLUM et al., 1999). A variable percentage of stallions infected by EAV (ranging from 10\% - 70\%) will subsequently become asymptomatic carriers and thus ensure viral persistence in various horse populations worldwide. Stallions with a persistent infection can be divided into three categories on the basis of the duration of virus excretion in their semen: short-term (from 1 to 5 weeks following clinical recovery), intermediate-term ( 3 to 7 months), and long-term carrier stallions (8 months to several years, or even all life) (TIMONEY et al., 1987; TIMONEY and MCCOLLUM, 1993). Their role is central in the epidemiology of EAV infection, and stallions can potentially transmit the virus to susceptible mares by artificial insemination or natural mating. These stallions may also represent a further source of new outbreaks due to the emergence of new pathogenic strains (TIMONEY, 1986; TIMONEY et al., 1986; MISZCZAK et al., 2012; MISZCZAK et al., 2015). Nonetheless, the spontaneous clearance of the virus in 4 to $40 \%$ of stallions may occur after several months or years (TIMONEY and MCCOLLUM, 2000).

The virus persists in the reproductive tract, mainly in the ampulla of the vas deferens, but also in the accessory sex glands (NEU et al., 1987). The mechanism of EAV persistence in stallions has still not been fully defined, but the establishment and maintenance of the carrier state are testosterone-dependent (LITTLE et al., 1991; HOLYOAK et al., 1993b; MCCOLLUM et al., 1994). In vitro studies suggest that horses could be divided into susceptible and resistant phenotypes, according to the susceptibility of their CD3(+) $\mathrm{T}$ lymphocytes to infection by EAV (GO et al., 2012). This susceptibility has a genetic basis that has been demonstrated in four breeds (GO et al., 2011). EAV interacts with some cellular elements in order to evade the equine immune response, and to establish persistent infection in the cells of the stallion's reproductive tract (BALASURIYA et al., 2018; CAROSSINO et al., 2018). After acute experimental EVA infection, stallions may undergo a period of temporary subfertility that can persist for up to 16 weeks before returning to pre-exposure fertility levels (NEU et al., 1987; TIMONEY and MCCOLLUM, 1993).

Various methods have been applied to eradicate EAV from infected semen, or to develop therapeutic treatment of EVA in stallions with persistent infections. Some of these methods have attempted to eliminate EAV from infected equine semen by using density gradient or single layer centrifugation, although the efficacy of these procedures has been variable (GOLNIK et al., 2004; MORRELL and GERAGHTY, 2006; MORRELL et al., 2013). Others have proposed the temporary chemical castration of infected stallions with an antagonist of the gonadotrophin-releasing hormone $(\mathrm{GnRH})$, or an anti-GnRH vaccine. After treatment with a GnRH antagonist for 35 days, FORTIER et al. (2002) failed to induce total virus clearance in EAV shedder stallions, although testosterone concentrations and virus shedding both decreased transiently during the treatment. In a case study, BURGER et al. (2004) vaccinated one EAV shedder stallion with an antiGnRH vaccine (Improvac ${ }^{\mathrm{TM}}$, Zoetis, Australia). The stallion stopped shedding the virus in his semen 6 months after the first injection. Using a very similar anti-GnRH vaccine (Equity ${ }^{\mathrm{TM}}$, Zoetis, Australia), which was initially developed for controlling oestrus in mares (ELHAY et al., 2007), BURGER et al. (2006) vaccinated three EAV shedder stallions with Equity ${ }^{\mathrm{TM}}$ and one with Improvac ${ }^{\mathrm{TM}}$. EAV could 
no longer be isolated from the semen of all these stallions after a few months.

Here, we report in more detail the cases of these 3 stallions vaccinated with the anti-GnRH vaccine Equity ${ }^{\mathrm{TM}}$ and 13 other naturally infected EAV stallions shedding virus in their semen and vaccinated with the same vaccine. We monitored under field conditions: (a) the viral load in their semen and (b) the evolution of their reproductive capacity (testosterone secretion and fertility).

\section{Materials and methods}

Stallions. Sixteen adult stallions from 16 different locations were included in this field study (Table 1). They belonged to various breeds and their ages ranged between 5 and 24 years (11/16 stallions were 14-20 years old). All had been naturally infected with EAV and subsequently became virus shedders in their semen. Seven stallions (J-P) had been infected during or subsequent to the 2007 French EAV outbreak. Sporadic infection was responsible in the remaining cases. After two consecutive positive viral diagnoses in semen by routine tests (RT-PCR and virus isolation), all the stallions were confirmed to be EAV positive, shedding virus in their semen. At the time of investigation, the stallions had shown virus shedding in their semen for different durations: short-term $(\mathrm{n}=1)$, intermediate-term $(\mathrm{n}=8)$ and long-term $(\mathrm{n}=7)$, according to TIMONEY et al. (1987) and TIMONEY and McCOLLUM (1993).
Anti-GnRH vaccination. All stallions were vaccinated intramuscularly twice with $200 \mu \mathrm{g}$ of a GnRH peptide-protein conjugate (Equity ${ }^{\mathrm{TM}}$ ) (ELHAY et al., 2007) 4 to 6 weeks apart. One stallion (I) received a third injection, 15 months after the first one, because EAV was still detected in his semen and his plasmatic testosterone level was increasing. This protocol was used safely by JANETT et al. (2009). A short clinical examination (rectal temperature, development of cutaneous reactions) was performed by veterinary practitioners following each vaccination.

Sampling protocol. A periodic sampling protocol (semen for viral load and blood for plasma testosterone concentration) was proposed systematically to the stud managers before and after vaccination. It was planned that samples would continue to be sent to the laboratories until both EAV clearance and restoration of normal plasma testosterone concentration were obtained.

Determination of plasma testosterone level. Plasma samples were sent to the INRA laboratory of Nouzilly (France) and kept frozen $\left(-20{ }^{\circ} \mathrm{C}\right)$. Plasma testosterone levels were determined using a direct radio-immunoassay method adapted from DEREVIERS et al. (1990) and ROTA et al. (2018). The intra- and inter-assay coefficients of variation were $5.7 \%$ and $5.9 \%$, respectively, for quality control plasma samples containing $0.5 \mathrm{ng} / \mathrm{mL}$ testosterone.

Table 1. Characteristics of the 16 stallions shedding equine arteritis virus (EAV) in their semen and vaccinated with the anti-GnRH vaccine Equity ${ }^{\mathrm{TM}}$

\begin{tabular}{|c|c|c|c|c|c|c|c|}
\hline \multirow[b]{2}{*}{ Stallion } & \multirow[b]{2}{*}{ Breed } & \multirow{2}{*}{$\begin{array}{l}\text { Country } \\
\text { of } \\
\text { location }\end{array}$} & \multirow{2}{*}{$\begin{array}{l}\text { Stallion } \\
\text { age } \\
\text { (years) }\end{array}$} & \multirow{2}{*}{$\begin{array}{l}\text { Known as EAV } \\
\text { shedder since } \\
\text { (month / year) }\end{array}$} & \multicolumn{2}{|c|}{$\begin{array}{c}\text { Period of } \\
\text { EAV shedding } \\
\text { before vaccination }\end{array}$} & \multirow{2}{*}{$\begin{array}{l}\text { Date of first } \\
\text { injection of anti- } \\
\text { GnRH vaccine } \\
\text { (month / year) }\end{array}$} \\
\hline & & & & & $\begin{array}{l}\text { No. of } \\
\text { months }\end{array}$ & Status* & \\
\hline A & Standardbred & $\begin{array}{l}\text { Switzer- } \\
\text { land }\end{array}$ & 16 & Jul 2004 & 1 & short & Aug 2004 \\
\hline B & Thoroughbred & France & 17 & Nov 2001 & 32 & long & Jul 2004 \\
\hline $\mathrm{C}$ & Thoroughbred & France & 16 & Apr 2000 & 49 & long & Jul 2004 \\
\hline $\mathrm{D}$ & Arabian & France & 16 & Feb 2006 & 3 & intermediate & May 2006 \\
\hline $\mathrm{E}$ & Anglo-Arab & France & 15 & Feb 2006 & 3 & intermediate & May 2006 \\
\hline $\mathrm{F}$ & Holstein & France & 17 & Jan 2006 & 6 & intermediate & Jul 2006 \\
\hline $\mathrm{G}$ & Thoroughbred & France & 12 & May 2005 & 19 & long & Dec 2006 \\
\hline
\end{tabular}


Table 1. Characteristics of the 16 stallions shedding equine arteritis virus (EAV) in their semen and vaccinated with the anti-GnRH vaccine Equity ${ }^{\mathrm{TM}}$ (continued)

\begin{tabular}{|c|c|c|c|c|c|c|c|}
\hline \multirow[b]{2}{*}{ Stallion } & \multirow[b]{2}{*}{ Breed } & \multirow{2}{*}{$\begin{array}{l}\text { Country } \\
\text { of } \\
\text { location }\end{array}$} & \multirow{2}{*}{$\begin{array}{l}\text { Stallion } \\
\text { age } \\
\text { (years) }\end{array}$} & \multirow{2}{*}{$\begin{array}{l}\text { Known as EAV } \\
\text { shedder since } \\
\text { (month / year) }\end{array}$} & \multicolumn{2}{|c|}{$\begin{array}{c}\text { Period of } \\
\text { EAV shedding } \\
\text { before vaccination }\end{array}$} & \multirow{2}{*}{$\begin{array}{l}\text { Date of first } \\
\text { injection of anti- } \\
\text { GnRH vaccine } \\
\text { (month / year) }\end{array}$} \\
\hline & & & & & $\begin{array}{l}\text { No. of } \\
\text { months }\end{array}$ & Status* & \\
\hline $\mathrm{H}$ & Anglo-Arab & France & 14 & Feb 2006 & 12 & long & Feb 2007 \\
\hline I & Anglo-Arab & France & 24 & Oct 2006 & 4 & intermediate & Feb 2007 \\
\hline $\mathrm{J}$ & $\begin{array}{l}\text { French saddle } \\
\text { horse }\end{array}$ & France & 18 & Nov 2007 & 6 & intermediate & May 2008 \\
\hline $\mathrm{K}$ & New Forest & France & 16 & Aug 2007 & 9 & long & May 2008 \\
\hline $\mathrm{L}$ & Anglo-Arab & France & 16 & Feb 2008 & 3 & intermediate & May 2008 \\
\hline M & $\begin{array}{l}\text { Foreign } \\
\text { (Polish) }\end{array}$ & France & 10 & Aug 2007 & 9 & long & May 2008 \\
\hline $\mathrm{N}$ & Lusitanian & France & 17 & Aug 2007 & 9 & long & May 2008 \\
\hline $\mathrm{O}$ & $\begin{array}{c}\text { French } \\
\text { Standardbred }\end{array}$ & France & 7 & Mar 2008 & 4 & intermediate & Jul 2008 \\
\hline $\mathrm{P}$ & $\begin{array}{l}\text { French saddle } \\
\text { Pony }\end{array}$ & France & 5 & Jan 2008 & 6 & intermediate & Jul 2008 \\
\hline
\end{tabular}

* Status of the stallion for EAV shedding, based on the duration of virus excretion in semen before vaccination: short-term (from 1 to 5 weeks after clinical recovery), intermediate-term (3 to 7 months) and long-term carrier stallion (from 8 months to years) according to Timoney et al. (1987) and Timoney and McCollum (1993).

Healthy stallions produce fertile spermatozoa throughout the year, despite the yearly endogenous rhythm of reproductive hormones. Plasma testosterone in the stallion is higher during the breeding season (from April to July) compared to the non-breeding season (August to March) with concentrations ranging from 0.3 , to more than $1.7 \mathrm{ng} / \mathrm{mL}$ throughout the year (RAESIDE, 1979; THOMPSON et al., 1985; ROSER and HUGHES, 1992; SIEME et al., 2001). Therefore, we defined a threshold of $0.3 \mathrm{ng} / \mathrm{mL}$ to decide if stallions presented low testosterone levels.

Viral detection and quantification. Chilled semen samples were sent immediately to the Labeo Frank Duncombe laboratory (France), where an aliquot was taken and kept frozen $\left(-80^{\circ} \mathrm{C}\right)$. Viral load was then estimated following retrospective analysis by qRT-PCR.

RNA purification: Equine semen was microcentrifuged at $13,800 \mathrm{~g}$ for $2 \mathrm{~min}$ and 140 $\mu \mathrm{L}$ of the supernatant was used for nucleic acid purification. Viral RNA was extracted using the
QIAamp ${ }^{\circledR}$ Viral RNA isolation kit (Qiagen, Hilden, Germany), and eluted in a final volume of $60 \mu \mathrm{L}$ according to the manufacturer's instructions.

Generation of in vitro transcribed RNA. An in vitro transcribed (IVT) EAV RNA containing complete ORF7 was used for EAV quantification. The IVT RNA was generated using the MEGAshortscript ${ }^{\mathrm{TM}}$ Kit (Ambion Inc., Austin, TX, USA) according to the manufacturer's instructions, and adapted from a previous study (LU et al., 2008). The IVT RNA transcripts were stored at $-80{ }^{\circ} \mathrm{C}$ until use. The RNA transcripts were quantified by spectrophotometric analysis using the NanoDrop 2000c (Thermo Fischer Scientific) and concentration of copy per microliter was calculated. The IVT RNA stock solution was quantified at $6.0 \times 10^{3} \mathrm{ng} / \mu \mathrm{L}$ and the IVT copy number was evaluated at $8.5 \times 10^{13}$ copy per $5 \mu \mathrm{L}$ (nucleic acid reaction volume in RTPCR) according to a previously described method (MISZCZAK et al., 2011). The dilution of IVT RNA ( $10^{10}$ to 1 copy) was carried out in RNase- and DNase-free molecular biology grade water. 
EAV real-time RT-PCR detection and quantification. A previously described one-tube realtime TaqMan RT-PCR assay, targeting the ORF7 of the EAV genome encoding the nucleocapsid, was used for EAV detection and quantification (BALASURIYA et al., 2002). Quantitative RT-PCR was performed using the One Step PrimeScript ${ }^{\mathrm{TM}}$ RT-PCR Kit (Perfect Real Time) (TaKaRa, Otsu, Japan) in a SmartCycler ${ }^{\circledR}$ II System (Cepheid, Sunnyvale, CA, USA). Briefly, each reaction was set up in $25 \mu \mathrm{L}$, according to the manufacturer's instructions, which contained $12.5 \mu \mathrm{L}$ of $2 \mathrm{X}$ One Step RT-PCR buffer III, $0.5 \mu \mathrm{L}$ of both TaKaRa Ex Taq $^{\mathrm{TM}} \mathrm{HS}(5 \mathrm{U} / \mu \mathrm{L})$ and PrimeScript ${ }^{\mathrm{TM}}$ RT enzyme Mix II, $600 \mathrm{nM}$ of forward and reverse primers ( $0.75 \mu \mathrm{L}$ of each), $200 \mathrm{nM}$ of probe $(0.5 \mu \mathrm{L}), 4.75$ $\mu \mathrm{L}$ of nuclease-free water and $5 \mu \mathrm{L}$ of test sample RNA. The following thermocycling conditions were used for each reaction: $5 \mathrm{~min}$ at $42{ }^{\circ} \mathrm{C}, 10 \mathrm{~s}$ at $95^{\circ} \mathrm{C}$, followed by 45 cycles at $95^{\circ} \mathrm{C}$ for $5 \mathrm{~s}$ and 60 ${ }^{\circ} \mathrm{C}$ for $1 \mathrm{~min}$. The analytical quantification of EAV in semen samples was performed in EAV nucleic acid by real-time PCR assay, with serial decimal dilutions of IVT RNA $\left(10^{10}-10^{1}\right.$ copy). Linearity of the regression analysis and PCR efficiency in the assay gave an $R^{2}=0.997$ and linear equation $\mathrm{y}=-3.653 \mathrm{x}+47.689$, respectively. Quantification of EAV viral load in each semen sample was determined by comparison with quantified serial decimal dilutions of IVT RNA. For each assay, the nucleic acid extracted from the semen samples and serial dilutions of IVT RNA were processed in duplicate.

Evaluation of fertility. Fertility was assessed for all French stallions according to the foaling rate determined by SIRE (French data base for horse registration, I.F.C.E., Pompadour, France), and defined as the number of mares declared as having delivered a foal, divided by the total number of mares bred by this stallion, either by hand mating or by artificial insemination with fresh semen, used immediately after collection during the breeding season under consideration. Mares inseminated with frozen semen were excluded from this calculation.

Irregular data. The sampling protocol (blood collection for determination of testosterone concentration, semen collection for viral load analysis) was adapted by the stud managers, and the stallions were not always sampled at the expected time-points (Fig. 1 and Tables 2 and 3). Prior to the first immunization, plasma testosterone concentration was measured at least once (except for stallions A and G). Stallion A, a male not used in reproduction, was only monitored for viral excretion, but not regarding testosterone secretion. Stallion $\mathrm{G}$ was not analysed for plasmatic testosterone concentration before and just after vaccination, but was sampled at month 11 when, EAV negative, he was unable to breed mares successfully. Stallion $\mathrm{C}$ died 7 months post-vaccination due to cardiac problems that were not related to the immunization protocol. Stallion P was only monitored for EAV by regular RT-PCR without viral load quantification before the first injection and no testosterone sampling was performed between the first and 7 months.

Policy and ethics. This study complied with French and Swiss laws relating to animal experimentation. The horses evaluated in this experiment were not research animals, and were managed with a high level of care. Their husbandry and care were carried out under their owners' responsibility. The owners were informed, and consented to participate in this study.

Statistical analyses. Non-parametric statistics were used due to the small number of subjects and the nature of the measurements. Data were analysed with XLSTAT software (Addinsoft, Paris, France). Data on virus content and testosterone levels were presented by medians and shown in box-plot form, in accordance with Tukey's model (TUKEY, 1977). The results concerning virus content and testosterone levels were not considered as matched data due to missing samples for some time points. The values for each time point were compared using the Kruskal-Wallis test. When the Kruskal-Wallis test was significant, post hoc (multiple comparisons) tests were performed with the Steel-Dwass-Critchlow-Fligner procedure. The comparisons were made across time-points, and mainly with respect to pre-vaccination values. 


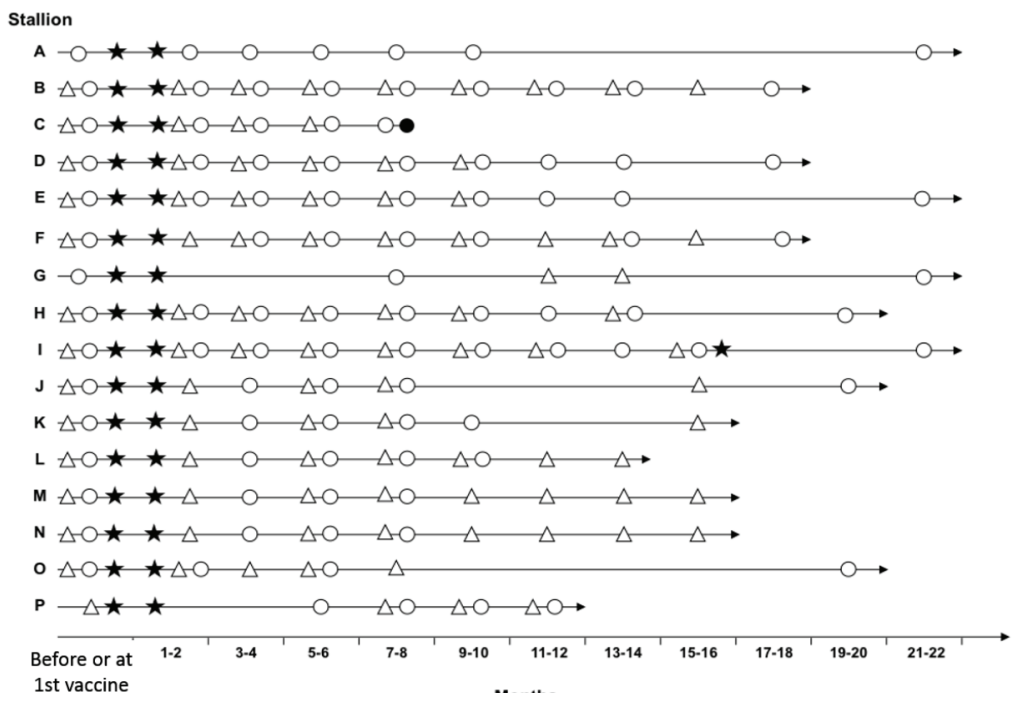

Fig. 1. Chronology and frequency of analyses performed in 16 stallions shedding EAV in their semen before and after vaccination with the anti-GnRH vaccine Equity ${ }^{\mathrm{TM}}$ (EAV: Equine arteritis virus) (in months after the first injection). $\bigcirc$ EAV detection and viral load quantification in semen sample. $\triangle$ Testosterone analysis in serum sample. $\star$ Vaccination with the Equity ${ }^{\mathbb{B}}$ vaccine.

- Death of stallion C. Stallion I received a third injection because EAV was still detected in his semen at month 15 and because testosterone was increasing. At the first injection, stallion P was only monitored by regular RT-PCR as an EAV shedder without viral load quantification.

Table 2. Plasmatic testosterone concentrations in stallions shedding EAV in their semen before and after anti-GnRH vaccination with Equity ${ }^{\mathrm{TM}}$. (EAV: Equine arteritis virus)

\begin{tabular}{|c|c|c|c|c|c|c|c|c|c|}
\hline \multirow[b]{3}{*}{ Stallion } & \multicolumn{9}{|c|}{ Plasma testosterone concentration (ng/mL) } \\
\hline & \multirow{2}{*}{$\begin{array}{l}\text { Before } \\
\text { or at } 1^{\text {st }} \\
\text { injection }\end{array}$} & \multicolumn{8}{|c|}{ Months after vaccination ( $1^{\text {st }}$ injection $)$} \\
\hline & & $1-2$ & $3-4$ & $5-6$ & $7-8$ & $9-10$ & $11-12$ & $13-14$ & $15-16$ \\
\hline $\mathrm{A}^{1}$ & $\begin{array}{c}\text { Never } \\
\text { sampled }\end{array}$ & $\begin{array}{c}\text { Never } \\
\text { sampled }\end{array}$ & $\begin{array}{c}\text { Never } \\
\text { sampled }\end{array}$ & $\begin{array}{c}\text { Never } \\
\text { sampled }\end{array}$ & $\begin{array}{c}\text { Never } \\
\text { sampled }\end{array}$ & $\begin{array}{c}\text { Never } \\
\text { sampled }\end{array}$ & $\begin{array}{c}\text { Never } \\
\text { sampled }\end{array}$ & $\begin{array}{c}\text { Never } \\
\text { sampled }\end{array}$ & $\begin{array}{c}\text { Never } \\
\text { sampled }\end{array}$ \\
\hline $\mathrm{B}$ & 2.0 & 0.1 & 0.1 & 0.1 & 0.2 & 1.2 & 0.6 & 2.2 & 0.5 \\
\hline $\mathrm{C}^{2}$ & 0.6 & 0.1 & 0.0 & 1.1 & / & Dead & Dead & Dead & Dead \\
\hline $\mathrm{D}$ & 1.5 & 0.2 & 0.2 & 0.3 & 0.3 & 0.8 & / & l & / \\
\hline $\mathrm{E}$ & 1.7 & 0.2 & 0.2 & 0.2 & 0.6 & 1.2 & 1 & 1 & 1 \\
\hline $\mathrm{F}$ & 1.5 & 0.5 & 0.2 & 0.2 & 0.3 & 0.2 & 0.2 & 0.2 & 0.3 \\
\hline $\mathrm{G}$ & 1 & 1 & 1 & 1 & 1 & 1 & 0.1 & 0.3 & 1 \\
\hline $\mathrm{H}$ & 0.7 & 0.2 & 0.3 & 0.2 & 0.2 & 0.3 & 1 & 0.1 & I \\
\hline $\mathrm{I}^{3}$ & 0.7 & 0.2 & 0.3 & 0.3 & 0.4 & 0.5 & 1.4 & 1 & 1.0 \\
\hline $\mathrm{J}$ & 2.1 & 0.9 & 1 & 0.2 & 1.1 & 1 & 1 & 1 & 1.1 \\
\hline $\mathrm{K}$ & 1.7 & 0.4 & 1 & 0.5 & 0.8 & 1 & 1 & 1 & 0.6 \\
\hline $\mathrm{L}$ & 1.7 & 0.4 & 1 & 0.2 & 0.3 & 0.5 & 0.5 & 0.2 & 1 \\
\hline $\mathrm{M}$ & 1.7 & 1.2 & 1 & 0.2 & 0.2 & 0.2 & 0.1 & 0.1 & 0.1 \\
\hline $\mathrm{N}$ & 2.1 & 1.8 & 1 & 0.1 & 0.1 & 0.2 & 0.1 & 0.0 & 0.1 \\
\hline $\mathrm{O}$ & 2.4 & 0.4 & 0.2 & 0.3 & 0.3 & 1 & 1 & 1 & 1 \\
\hline $\mathrm{P}$ & 1.6 & 1 & 1 & 1 & 1.0 & 1.3 & 1.8 & 1 & 1 \\
\hline
\end{tabular}

"/": no sampling; Plasmatic testosterone concentration values lower or equal to $0.3 \mathrm{ng} / \mathrm{mL}$ are highlighted in grey; ${ }^{1}$ Stallion A was not a reproductive stallion; ${ }^{2}$ Stallion $\mathrm{C}$ died at month 7 for reasons not related to the vaccination protocol; ${ }^{3}$ Stallion I was vaccinated a third time at month 15 period. 


\section{Results}

All results, tables and figures are presented with respect to the number of months after the $1^{\text {st }}$ injection of vaccine.

Vaccine tolerance. After immunization, only a transient rise in body temperature or a small transient painful swelling at the injection site was detected in some stallions. All adverse effects resolved within 2-3 days post-vaccination.

Plasma testosterone level. Plasma concentrations of testosterone ranged from 0.6 to $2.4 \mathrm{ng} / \mathrm{mL}$ (median: $1.7 \mathrm{ng} / \mathrm{mL}$ ) before the first injection (Table 2 and Fig. 2A). When compared to the pre-vaccination value, testosterone concentration after injections decreased during months 1-2 (0.4 to $1.7 \mathrm{ng} / \mathrm{mL})(\mathrm{P}<0.005)$ and remained generally low until months 5-6 $(0.2 \mathrm{ng} / \mathrm{mL}) \quad(\mathrm{P}<0.001)$. Thereafter, testosterone concentrations tended to increase during months 7 to 10 , but still remained below pre-vaccination levels 11 to 12 months postvaccination (Fig. 2A). During the first 6 months after the first injection, 11 out of 13 stallions showed, at least once, a plasma testosterone concentration lower or equal to $0.3 \mathrm{ng} / \mathrm{mL}$. After 5-6 months, two groups of stallions were observed. One group of 9 stallions (B-D, E, I-L and P) showed increased testosterone levels $(\geq 0.5 \mathrm{ng} / \mathrm{mL})$, the other group of 6 stallions (F-H and M-O) still had low testosterone concentrations $(\leq 0.3 \mathrm{ng} / \mathrm{mL})$.

$E A V$ detection and quantification in semen. Before vaccination, or at the time of the first injection, the EAV viral load ranged from $9.4 \times 10^{7}$ to $2.2 \times 10^{10} \mathrm{RNA}$ copy $/ \mathrm{mL}$ of semen (median: $3.2 \times 10^{9}$ RNA copy/mL of semen) (Table 3 and Fig. 2B). Thereafter, the EAV viral load decreased at months 3-4 $(\mathrm{P}<0.0001)$ and remained low (for instance at months 5-6: median $1.1 \times 10^{6} \mathrm{RNA}$ copy $/ \mathrm{mL}$ of semen, $\mathrm{P}<0.0001)$ compared to pre-vaccination values. The median values were 0 (undetectable) from months 7-8 to months 9-12 (end of Fig. 2B) and until months 21-22.
A

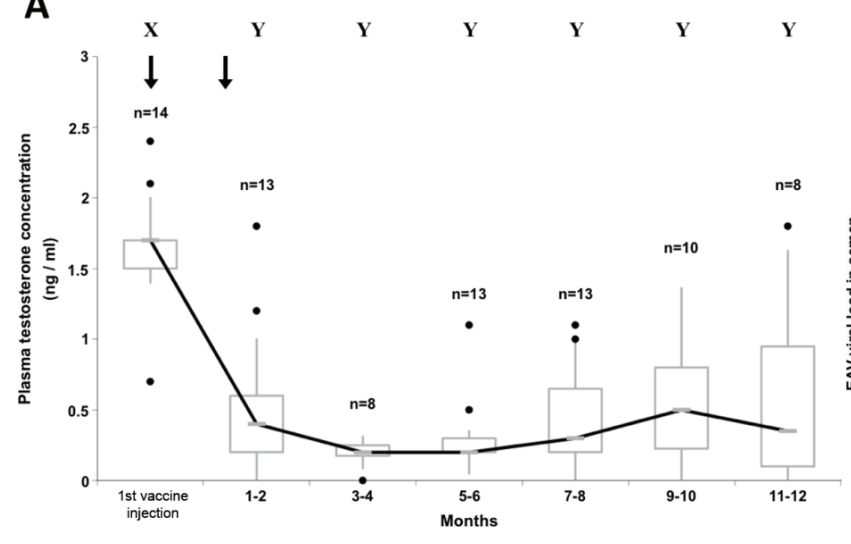

B

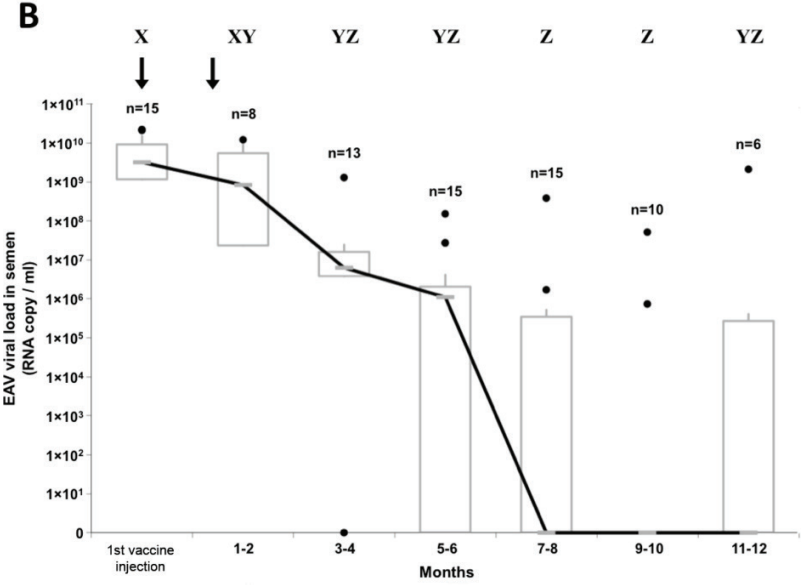

Fig. 2. Evolution of plasma testosterone concentrations (A) and EAV viral load in the semen (B) of 16 stallions shedding EAV in their semen before and over 12 months after vaccination with the anti-GnRH vaccine Equity ${ }^{\mathrm{TM}}$ (EAV: Equine arteritis virus) (in months after the first injection). $\downarrow$ - injection of anti-GnRH vaccine; Box and whisker plots represent the heterogeneity of the stallion population at each time period (every two months). Boxes represent the interquartile (IQ = Q3-Q1) ranges of plasma testosterone concentrations (A) and EAV viral load in semen (B). The bottom and top of the boxes represent the $1^{\text {st }}(\mathrm{Q} 1)$ and $3^{\text {rd }}(\mathrm{Q} 3)$ quartiles, respectively, and the horizontal lines inside the boxes represent the median values. Vertical lines emanating from each box are limited by the minimal value for lower whisker and by mathematical calculation of upper whisker plots $(\mathrm{UW}=\mathrm{Q} 3+1.5 \times \mathrm{IQ})$. Outliers (values $>\mathrm{UW}$ ) are represented by black dots. $\mathrm{n}-$ number of stallions included at each time point. The letters (X, Y, Z) indicate significant differences between times (Fig. 2A - P $\leq 0.01$; Fig. $2 \mathrm{~B}-\mathrm{P} \leq 0.03)$. 
Table 3. Quantification of viral load (EAV) in semen samples of 16 stallions before and after vaccination with the anti-GnRH vaccine Equity ${ }^{\mathrm{TM}}$

\begin{tabular}{|c|c|c|c|c|c|c|c|c|c|c|c|c|}
\hline \multirow[b]{3}{*}{ Stallion } & \multicolumn{12}{|c|}{ Number of RNA copy of EAV (copy/mL) in semen* } \\
\hline & \multirow{2}{*}{$\begin{array}{c}\text { Before } \\
\text { or at } 1^{\text {st }} \\
\text { injection }\end{array}$} & \multicolumn{11}{|c|}{ Months after vaccination ( $1^{\text {st }}$ injection $)$} \\
\hline & & $1-2$ & $3-4$ & $5-6$ & $7-8$ & $9-10$ & $11-12$ & $13-14$ & $15-16$ & $17-18$ & $19-20$ & $21-22$ \\
\hline $\mathrm{A}^{1}$ & $2.2 \times 10^{10}$ & $6.4 \times 10^{9}$ & $6.3 \times 10^{6}$ & $3.4 \times 10^{5}$ & $4.5 \times 10^{5}$ & 0 & / & / & / & / & / & 0 \\
\hline $\mathrm{B}$ & $1.2 \times 10^{10}$ & $1.2 \times 10^{10}$ & $1.6 \times 10^{7}$ & $7.7 \times 10^{5}$ & 0 & 0 & 0 & 0 & / & 0 & 1 & 1 \\
\hline $\mathrm{C}^{2}$ & $2.1 \times 10^{10}$ & $5.5 \times 10^{4}$ & $3.8 \times 10^{6}$ & $1.1 \times 10^{6}$ & $2.4 \times 10^{5}$ & dead & dead & dead & dead & dead & dead & dead \\
\hline $\mathrm{D}$ & $9.4 \times 10^{7}$ & $3.1 \times 10^{7}$ & $5.1 \times 10^{4}$ & 0 & 0 & 0 & 0 & 0 & 1 & 0 & 1 & 1 \\
\hline $\mathrm{E}$ & $8.5 \times 10^{9}$ & $5.2 \times 10^{9}$ & $5.7 \times 10^{6}$ & $2.7 \times 10^{7}$ & 0 & 0 & 0 & 0 & 1 & 1 & 1 & 0 \\
\hline $\mathrm{F}$ & $9.9 \times 10^{9}$ & 1 & $5.7 \times 10^{6}$ & $2.0 \times 10^{6}$ & $5.1 \times 10^{5}$ & 0 & 1 & 0 & 1 & 0 & 1 & 1 \\
\hline $\mathrm{G}$ & $2.6 \times 10^{9}$ & 1 & / & / & 0 & 1 & 1 & / & 1 & 1 & 1 & 0 \\
\hline $\mathrm{H}$ & $5.8 \times 10^{9}$ & $1.7 \times 10^{8}$ & $1.7 \times 10^{7}$ & $2.4 \times 10^{6}$ & $1.7 \times 10^{6}$ & $7.3 \times 10^{5}$ & $3.6 \times 10^{5}$ & $1.0 \times 10^{5}$ & 1 & 1 & 0 & 1 \\
\hline $\mathrm{I}^{3}$ & $3.4 \times 10^{9}$ & $1.5 \times 10^{9}$ & $1.3 \times 10^{9}$ & $1.5 \times 10^{8}$ & $3.8 \times 10^{8}$ & $5.1 \times 10^{7}$ & $2.1 \times 10^{9}$ & $7.1 \times 10^{7}$ & $2.1 \times 10^{5}$ & 1 & / & 0 \\
\hline $\mathrm{J}$ & $8.3 \times 10^{8}$ & 1 & $2.1 \times 10^{7}$ & $1.6 \times 10^{6}$ & $1.7 \times 10^{5}$ & 1 & 1 & 1 & 1 & 1 & 0 & 1 \\
\hline $\mathrm{K}$ & $1.5 \times 10^{9}$ & 1 & 0 & 0 & 0 & 0 & / & 1 & 1 & 1 & I & 1 \\
\hline $\mathrm{L}$ & $4.0 \times 10^{8}$ & 1 & $7.9 \times 10^{6}$ & $1.2 \times 10^{6}$ & 0 & 0 & 1 & 1 & 1 & 1 & 1 & 1 \\
\hline$M$ & $6.6 \times 10^{8}$ & 1 & $1.1 \times 10^{7}$ & 0 & 0 & 1 & 1 & 1 & 1 & 1 & 1 & 1 \\
\hline $\mathrm{N}$ & $2.5 \times 10^{9}$ & 1 & 0 & 0 & 0 & 1 & 1 & 1 & / & 1 & 1 & 1 \\
\hline $\mathrm{O}$ & $3.2 \times 10^{9}$ & $1.9 \times 105$ & 1 & 0 & 1 & 1 & 1 & 1 & 1 & 1 & 0 & 1 \\
\hline $\mathrm{P}^{4}$ & + & 1 & 1 & 0 & 0 & 0 & 1 & 1 & 1 & 1 & I & \\
\hline
\end{tabular}

* Number of RNA copy/mL of semen sample and detected by qRT-PCR. “””: no sampling; “+”: EAV positive sample detected by regular RT-PCR without quantification; "0": undetectable = negative results, all negative results are highlighted in grey; ${ }^{1}$ - Stallion A was not a reproductive stallion; ${ }^{2}$ - Stallion $\mathrm{C}$ died at month 7 for reasons not related to the vaccination protocol; ${ }^{3}$ - Stallion I was vaccinated a third time at month $15 ;{ }^{4}$ - At first injection, Stallion P was only monitored by regular RT-PCR without viral load quantification.

At the end of the experiment, EAV clearance was observed in all stallions (except for stallion C, who died in month 7). Most of the stallions (12 out of 15) became EAV negative between months 3 and 10 (A, $\mathrm{B}, \mathrm{D}-\mathrm{G}$ and K-P). Stallions $\mathrm{H}$ and I presented EAV viral loads of $1.0 \times 10^{5}$ and $2.1 \times 10^{5} \mathrm{RNA}$ copy $/ \mathrm{mL}$ at months 13-14 and 15-16, respectively. Threestallions $(\mathrm{H}, \mathrm{I}, \mathrm{J})$ became EAV negative after 18 months.

Moreover, all stallions were confirmed as having EAV negative semen by qRT-PCR and virus isolation at least once during the breeding season following their first EAV negative result.

Fertility at the first breeding season postvaccination. Of the 16 stallions monitored at the start of the study, 14 had produced foals before (Table 4), and were expected to breed mares again during the season following the vaccination, so within 12 months. Of these 14 stallions, 2 were not used since they were still EAV positive at the start of the following breeding season ( $\mathrm{H}$ and I). Of the 12 remaining stallions, 4 stallions were not used since they were unable to breed mares (F, G, M, N). Finally, 8 stallions (B-E, J-L, O and P) were EAV negative and bred mares successfully during the next breeding season (Table 4). For these 8 stallions, individual foaling rates ranged from 27 to $88 \%$ before vaccination and from 29 to $72 \%$ after vaccination; 18 foals per stallion (from 3 to 54 foals) were born from the mares bred during the last season before vaccination vs. 12 foals per stallion (ranging from 4 to 27 foals) during the season following the vaccination. 
Table 4. Fertility of stallions shedding EAV in their semen before and after vaccination with the anti-GnRH vaccine Equity $^{\mathrm{TM}}$. After vaccination, this concerns only the breeding season that took place within 12 months.

\begin{tabular}{|c|c|c|c|c|c|}
\hline \multirow[b]{2}{*}{ Stallion } & \multirow{2}{*}{$\begin{array}{c}\text { Breeding season } \\
\text { before becoming } \\
\text { EAV positive }\end{array}$} & \multicolumn{4}{|c|}{ First breeding season after vaccination } \\
\hline & & $\begin{array}{l}\text { EAV viral load } \\
\text { in semen }\end{array}$ & $\begin{array}{c}\text { Plasmatic } \\
\text { testosterone }\end{array}$ & Breeding & $\begin{array}{c}\text { Foaling rate } \\
(\%)\end{array}$ \\
\hline A & $\begin{array}{l}\text { Not breeding } \\
\text { stallion }\end{array}$ & 0 & Not measured & $\begin{array}{l}\text { Not breeding } \\
\text { stallion }\end{array}$ & \\
\hline $\mathrm{B}$ & 53 & 0 & $>=0.3 \mathrm{ng} / \mathrm{mL}$ & Yes & 29 \\
\hline $\mathrm{C}$ & 64 & Dead & Dead & Dead & \\
\hline $\mathrm{D}$ & 66 & 0 & $>=0.3 \mathrm{ng} / \mathrm{mL}$ & Yes & 55 \\
\hline $\mathrm{E}$ & 88 & 0 & $>=0.3 \mathrm{ng} / \mathrm{mL}$ & Yes & 72 \\
\hline $\mathrm{F}$ & 71 & 0 & Too low ${ }^{2}$ & No & \\
\hline G & 62 & 0 & Too low ${ }^{2}$ & No & \\
\hline $\mathrm{H}$ & 67 & Positive & Not measured & No & \\
\hline I & 57 & Positive & $>=0.3 \mathrm{ng} / \mathrm{mL}$ & No & \\
\hline $\mathrm{J}$ & 57 & 0 & $>=0.3 \mathrm{ng} / \mathrm{mL}$ & Yes & 57 \\
\hline $\mathrm{K}$ & 73 & 0 & $>=0.3 \mathrm{ng} / \mathrm{mL}$ & Yes & 58 \\
\hline $\mathrm{L}$ & 46 & 0 & $>=0.3 \mathrm{ng} / \mathrm{mL}$ & Yes & 50 \\
\hline M & 63 & 0 & Too low ${ }^{2}$ & No & \\
\hline $\mathrm{N}$ & 54 & 0 & Too low $^{2}$ & No & \\
\hline $\mathrm{O}$ & 69 & 0 & $=0.3 \mathrm{ng} / \mathrm{mL}$ & Yes & 68 \\
\hline $\mathrm{P}$ & 27 & 0 & $>=0.3 \mathrm{ng} / \mathrm{mL}$ & Yes & 56 \\
\hline
\end{tabular}

1 - Foaling rate: number of mares declared as having delivered a foal, divided by the total number of mares bred by this stallion. Only mares bred by hand mating or inseminated with fresh semen used immediately were taking into account in that ratio; ${ }^{2}-$ Too low: $<0.3 \mathrm{ng} / \mathrm{mL}$

\section{Discussion}

This report describes a cohort of naturally EAV infected stallions immunized with an anti-GnRH vaccine and monitored under field conditions. In most stallions, we observed a decrease followed by an increase in plasmatic testosterone levels. At the same time, in all stallions we observed a decrease of the EAV viral load in their semen until undetectable levels. Most stallions used in breeding produced foals during the following breeding season. These results were obtained from a cohort of stallions characterized by high heterogeneity with regard to location, breed, age and EAV status based on the previous duration of virus excretion in the semen. Therefore, this experimental group can be considered as being representative for the general population of domesticated stallions in Europe.
The significant and rapid decrease in testosterone levels observed in our study group during the first two months after anti-GnRH vaccination has already been reported by other authors with the vaccine Equity ${ }^{\mathrm{TM}}$ (JANETT et al., 2009), as well as with other anti-GnRH vaccines (MALMGREN et al., 2001; BURGER et al., 2004; STOUT and COLENBRANDER, 2004; CLEMENT et al., 2005; TURKSTRA et al., 2005). This observation is in agreement with the suppression of the cyclic ovarian activity in mares observed during the first months following vaccination with both Equity ${ }^{\mathrm{TM}}$ and Improvac ${ }^{\circledR}$ vaccines (CARD et al., 2007; ELHAY et al., 2007; SCHULMAN et al., 2013). 
In the present field study, the mean duration of decreased plasma testosterone concentrations $(\leq 0.3$ $\mathrm{ng} / \mathrm{mL}$ ) was 10 months (from months $1-2$ to months 11-12 post-vaccination) (Fig. 2A). This duration was variable among stallions and ranged from 4 to 16 months or more, but is in broad agreement with the duration of 6 months of very low testosterone levels previously observed in $4 / 5$ stallions after three injections of Equity ${ }^{\mathrm{TM}}$ (JANETT et al., 2009). Other vaccines used in stallions proved not to be so efficient and required more than two injections (MALMGREN et al., 2001; CLEMENT et al., 2005). Therefore, the Equity $^{\mathrm{TM}}$ vaccine can be considered as an efficient anti-GnRH vaccine for stallions which induces a significant decrease of testosterone plasma levels during 4 months and more.

The majority of the stallions' semen was shown to be EAV-free within 3 to 10 months post-vaccination, and all stallions were EAV-free after 22 months. Before or at the first injection with Equity ${ }^{\mathrm{TM}}$, the viral load ranged from $9.4 \times 10^{7}$ to $2.2 \times 10^{10} \mathrm{copy} / \mathrm{mL}$ of semen, which is a rather homogeneous result. Thereafter, the viral load decreased to $5.1 \times 10^{4}$ $2.7 \times 10^{7}$ copy $/ \mathrm{mL}$ (the general range being $10^{5}-10^{6}$ copy $/ \mathrm{mL}$ ) in the last semen sample before the first negative sample. In light of these findings, a viral load lower than $10^{5}-10^{6}$ copy $/ \mathrm{mL}$ of semen could be considered, in the majority of cases, as a predictive threshold value before total EAV clearance is reached.

It is not yet fully understood how spontaneous clearance of EAV happens in intact stallions. Monitoring EAV viral load and EAV clearance in semen was described previously by culture and/ or regular RT-PCR (BALASURIYA et al., 2018). By applying a quantitative approach, the present report gives new information about the evolution of EAV before clearance. This quantitative approach of viral output in carrier stallions could possibly be used to monitor natural clearance. However, in intact stallions, it takes place in an intact genital tract in the presence of testosterone, which was not the case here.

Previous studies revealed that testosterone plays an essential role in the establishment and maintenance of the carrier-state in persistently EAV infected stallions. EAV was cleared from carrier stallions 4 to 26 days post-castration, but viral excretion was maintained if castrated stallions were testosterone supplemented (LITTLE et al., 1991). In addition, it was not possible to establish a carrier state in experimentally EAV infected geldings (MCCOLLUM et al., 1994). The nature and extent of pathological changes in the reproductive tracts of prepubertal and peripubertal colts associated with EAV infection demonstrate the relationship between the stage of reproductive tract maturity and susceptibility (HOLYOAK et al., 1993a). Using a GnRH antagonist in EVA carrier stallions for 5 weeks, FORTIER et al. (2002) observed temporary EAV clearance just after treatment in all stallions, even though $2 / 5$ stallions subsequently regained their shedding state. The first case study described the clearance of the virus in a stallion six months after vaccination with the Improvac ${ }^{\mathbb{B}}$ vaccine, following a strong decrease in plasmatic testosterone concentration over five months (BURGER et al., 2004). Similarly, in our study, the decrease in plasma testosterone concentrations beginning 1-2 months after the first injection, and lasting 2 to 4 months or more, was followed by a significant decrease in viral load 3-4 months post-vaccination. It might be hypothesized that testosterone has to be reduced for 2 months or more to induce EAV clearance.

In the present study, the semen of all vaccinated stallions (15 out of the 15 stallions monitored for 22 months) became EAV negative after anti-GnRH vaccination: in 12 of them before 11 months and in 3 between 19 and 22 months (including a stallion with a third vaccine injection at 15 months). It cannot be concluded that all these viral clearances were a consequence of anti-GnRH vaccination, as spontaneous clearance may also have occurred at any time. The lack of a control group of mostly active breeding stallions with placebo treatment represents a major limitation of this field study. Nonetheless, it has been reported that the percentage of spontaneous EAV clearance following natural infection in a population of more than 200 stallions varied from 4 to $42 \%$, depending on the breed (TIMONEY and MCCOLLUM, 2000). If one considers this $42 \%$ as the maximum reference value 
for spontaneous EAV clearance, then the value of $100 \%$ ( 15 out of 15 stallions) observed in the present study is encouraging. Nonetheless, our results need to be confirmed in a controlled designed study.

In France, from 2005 to 2009, the foaling rate of Warmblood stallions was shown to be $62 \%$ after natural service and $68 \%$ after artificial insemination with fresh semen used immediately after collection (data on 3000 stallions per year). Before GnRH vaccination, all breeding stallions in our field study produced foals with a low to normal foaling rate, and presented normal testosterone levels. One year after anti-GnRH vaccination, two different populations of stallions could be identified according to their testosterone level: the first group showing plasma testosterone concentrations higher than $0.3 \mathrm{ng} /$ $\mathrm{mL}$ and able to breed and fertilize mares, and the second group of stallions presenting low plasma testosterone concentrations $(\leq 0.3 \mathrm{ng} / \mathrm{mL})$. In the first group, stallion $\mathrm{B}$, with the lowest foaling rate after the first breeding season post-vaccination $(29 \%, n=28$ mares), reached a foaling rate of $68 \%$ in the next breeding season ( $\mathrm{n}=44$ mares). Stallions from the first group seemed to regain the status of normal fertile breeding stallions after vaccination. However, regarding the second group of stallions, the risk of long-lasting reduced testosterone secretion after GnRH vaccination was confirmed. Indeed, one to two years after vaccination with the Equity $^{\mathrm{TM}}$ or Improvac ${ }^{\mathrm{TM}}$ vaccines, the rate of non-recovery of reproductive function has been estimated to be 8 to $40 \%$ in stallions and in mares (IMBODEN et al., 2006; CARD et al., 2007; ELHAY et al., 2007; JANETT et al., 2009; SCHULMAN et al., 2013). Some stallions in the second group may also have been affected by a spontaneous alteration of their reproductive capacity, i.e. by idiopathic subfertility/infertility observed in aged stallions. Scientists assume that at the beginning of this condition, there is an initial decline in important testicular factors necessary for interactions between Sertoli and germ cells. Leydig cell dysfunction, along with reduced testosterone secretion are observed only when the condition is severe (ROSER, 1997). On the other hand, if no stallions in the second group represented such a case, the risk of long-lasting immunocastration due to anti-GnRH vaccination could be estimated in our study cohort as being $31 \%$ (4 out of 13 stallions with data before or at 12 months). As such, this risk represents a major concern for the use of anti-GnRH vaccination in valuable breeding stallions, but was accepted by the owners of EAV shedding stallions in our study compared to surgical castration or culling. To counteract this untoward effect, an agonist of $\mathrm{GnRH}$, buserelin, was administered daily from 2 months before the beginning until the end of the breeding season in those 4 stallions. Three stallions subsequently presented daily increasing plasmatic testosterone concentrations and produced foals (VIDAMENT et al., 2010). This fact gives us an indication in favour of the longlasting immunocastration hypothesis, since $\mathrm{GnRH}$ supplementation was seldom efficient in idiopathic subfertile/infertile stallions (STOUT, 2005).

During follow-up, the characteristics of the semen and testes of the majority of the stallions were documented before and over 6-12 months after vaccination: evaluation of the number of spermatozoa per ejaculate, their motility and morphology, and measurement of testicular size by echography. Since these analyses were performed in field laboratories, the results have not been reported here. However, the stallions often presented a strong decrease in the number of spermatozoa, an increase in the number of detached heads, a reduction in testicular size, and a decreased libido. This was observed in both populations (see above) 4-6 months after vaccination. In the population of stallions with an increase in testosterone concentrations above $0.3 \mathrm{ng} / \mathrm{mL}$, production of spermatozoa and testicular size rose two months after this increase. The schedule of events was in agreement with those observed by JANETT et al., (2009) following vaccination with the Equity ${ }^{\mathrm{TM}}$ vaccine. Indeed, such modifications of testicular function are usually observed after any temporary insult to spermatogenesis (JOHNSON et al., 1997).

Finally, our results obtained without control stallions and with irregular field data should be interpreted with caution and need to be confirmed in a controlled designed study to evaluate viral clearance rate, as well as the risk of long lasting immunocastration after this type of immunization. 


\section{Conclusion}

In most stallions that were naturally EAV infected and then immunized with an anti-GnRH vaccine, a decrease was observed in plasmatic testosterone levels at month 1-6, lasting 4 months or more, as well as a decrease in viral load in the semen until undetectable levels at months 3-10. At months 9-10, most stallions showed an increasing plasmatic testosterone concentration again, but others still had very low levels until months 13-14. Most stallions produced foals during the following breeding season $(8 / 14)$, but the others were not usable (4 for reproductive deficiency and 2 for EAV positivity). All stallions finally had EAV negative semen at month 22. These results need to be confirmed in a controlled designed study.

\section{Conflict of interests}

None of the authors of this article has a financial or personal relationship with other people or organisations that could inappropriately influence or bias the content of this study.

\section{Acknowledgements}

We are grateful to all the managers and staff of the stud farms, and to all the veterinary practitioners who participated in this study. We thank Elisabeth Blesbois for reviewing this manuscript. This work received financial or material support from "IFCE" (French Institute for Horse and Riding), the "Conseil Général du Calvados" (France), the Hippolia Foundation (France) and the National Stud of Avenches from Agroscope (Switzerland).

\section{References}

BALASURIYA, U. B., C. M. LEUTENEGGER, J. B. TOPOL, W. H. MCCOLLUM, P. J. TIMONEY, N. J. MACLACHLAN (2002): Detection of equine arteritis virus by real-time TaqMan reverse transcription-PCR assay. J. Virol. Methods. 101, 21-28.

DOI: 10.1016/s0166-0934(01)00416-5

BALASURIYA, U. B. R., M. CAROSSINO, P. J. TIMONEY (2018): Equine viral arteritis: A respiratory and reproductive disease of significant economic importance to the equine industry. Equine Vet. Educ. 30, 497-512.

DOI: $10.1111 /$ eve. 12672

BURGER, D., F. JANETT, I. IMBODEN, S. ZIENTARA, P. TIMONEY, R. THUN (2004): Treatment of an equine arteritis virus-shedding stallion by immunization against GnRH. In: The $15^{\text {th }}$ International Congress on Animal Reproduction, Porto Seguro, Brazil, p. 281.

BURGER, D., F. JANETT, M. VIDAMENT, R. STUMP, G. FORTIER, I. IMBODEN, R. THUN (2006): Immunization against GnRH in adult stallions: Effects on semen characteristics, behaviour and shedding of equine arteritis virus. Anim. Reprod. Sci. 94, 107-111.

DOI: $10.1016 /$ j.anireprosci.2006.03.098
CARD, C., T. RAZ, R. LEHEIGET, G. SIBERT (2007): GnRF Immunization in Mares: ovarian function, return to cycling, and fertility. In: The Annual Convention of the AAEP, Orlando, FL, pp. 576-577.

CAROSSINO, M., P. DINI, T. S. KALBFLEISCH, A. T. LOYNACHAN, I. F. CANISSO, K. M. SHUCK, P. J. TIMONEY, R. F. COOK, U. B. R. BALASURIYA (2018): Downregulation of MicroRNA eca-mir-128 in seminal exosomes and enhanced expression of CXCL16 in the stallion reproductive tract are associated with long-term persistence of equine arteritis virus. J. Virol. 92.

DOI: 10.1128/JVI.00015-18

CLEMENT, F., M. VIDAMENT, P. DAELS, F. VAN DER MEER, J. L. LARRY, B. COLENBRANDER, J. TURKSTRA (2005): Immunocastration in stallions: effect on spermatogenesis and behaviour. Anim. Reprod. Sci. 89, 230-233.

DEREVIERS, M. T. H., M. COPIN, M. SECK, C. MONETKUNTZ, C. CORNU, I. FONTAINE, C. PERREAU, J. M. ELSEN (1990): Stimulation of testosterone production by PMSG injection in the ovine male - effect of breed and age and application to males carrying or not carrying the $\mathrm{F}$ booroola gene. Anim. Reprod. Sci. 23, 21-32.

DOI: 10.1016/0378-4320(90)90012-5

DOLL, E. R., R. E. KNAPPENBERGER, J. T. BRYANS (1957): An outbreak of abortion caused by the equine arteritis virus. Cornell Vet. 47, 69-75.

ELHAY, M., A. NEWBOLD, A. BRITTON, P. TURLEY, K. DOWSETT, J. WALKER (2007): Suppression of behavioural and physiological oestrus in the mare by vaccination against GnRH. Aust. Vet. J. 85, 39-45. DOI: 10.1111/j.1751-0813.2006.00092.x

FORTIER, G., M. VIDAMENT, F. DECRAENE, B. FERRY, P. F. DAELS (2002): The effect of GnRH antagonist on testosterone secretion, spermatogenesis and viral excretion in EVA-virus excreting stallions. Theriogenology 58, 425-427. DOI: 10.1016/s0093-691x(02)00848-8

GO, Y. Y., E. BAILEY, D. G. COOK, S. J. COLEMAN, J. N. MACLEOD, K. C. CHEN, P. J. TIMONEY, U. B. BALASURIYA (2011): Genome-wide association study among four horse breeds identifies a common haplotype associated with in vitro $\mathrm{CD} 3+\mathrm{T}$ cell susceptibility/ resistance to equine arteritis virus infection. J Virol. 85, 13174-13184.

DOI: 10.1128/JVI.06068-11

GO, Y. Y., E. BAILEY, P. J. TIMONEY, K. M. SHUCK, U. B. R. BALASURIYA (2012): Evidence that in vitro susceptibility of CD3(+) T lymphocytes to equine arteritis virus infection reflects genetic predisposition of naturally infected stallions to become carriers of the virus. J. Virol. $86,12407-12410$.

DOI: $10.1128 / J V I .01698-12$

GOLNIK, W., B. SORDYL, W. NIZANSKI, M. KLIMOWICZ (2004): Application of EquiPure to improve stallion sperm quality and its equine arteritis virus decontamination. Medycyna Wet. 60, 508-511.

HOLYOAK, G. R., R. C. GILES, W. H. MCCOLLUM, T. V. LITTLE, P. J. TIMONEY (1993a): Pathological changes 
associated with equine arteritis virus infection of the reproductive tract in prepubertal and peripubertal colts. J. Comp. Pathol. 109, 281-293.

DOI: 10.1016/S0021-9975(08)80253-8

HOLYOAK, G. R., T. V. LITTLE, W. H. MCCOLLUM, P. J. TIMONEY (1993b): Relationship between onset of puberty and establishment of persistent infection with equine arteritis virus in the experimentally infected colt. Journal of Comparative Pathology. 109, 29-46.

DOI: $10.1016 / \mathrm{S} 0021-9975(08) 80238-1$

IMBODEN, I., F. JANETT, D. BURGER, M. A. CROWE, M. HASSIG, R. THUN (2006): Influence of immunization against GnRH on reproductive cyclicity and estrous behavior in the mare. Theriogenology. 66, 1866-1875. DOI: 10.1016/j.theriogenology.2006.04.038

JANETT, F., R. STUMP, D. BURGER, R. THUN (2009): Suppression of testicular function and sexual behavior by vaccination against $\mathrm{GnRH}$ (Equity ${ }^{\mathrm{TM}}$ ) in the adult stallion. Anim. Reprod. Sci. 115, 88-102.

DOI: 10.1016/j.anireprosci.2008.11.011

JOHNSON, L., T. L. BLANCHARD, D. D. VARNER, W. L. SCRUTCHFIELD (1997): Factors affecting spermatogenesis in the stallion. Theriogenology. 48, 1199-1216.

DOI: $10.1016 / \mathrm{s} 0093-691 \mathrm{x}(97) 00353-1$

LITTLE, T. V., G. R. HOLYOAK, W. H. MCCOLLUM, P. J. TIMONEY (1991): Output of equine arteritis virus from persistently infected stallions is testosterone dependant. In: The $6^{\text {th }}$ International Conference on Equine Infectious Diseases, Cambridge, pp. 225-229.

LU, Z., A. J. BRANSCUM, K. M. SHUCK, J. ZHANG, E. J. DUBOVI, P. J. TIMONEY, U. B. BALASURIYA (2008): Comparison of two real-time reverse transcription polymerase chain reaction assays for the detection of Equine arteritis virus nucleic acid in equine semen and tissue culture fluid. J. Vet. Diagn. Invest. 20, 147-155. DOI: $10.1177 / 104063870802000202$

MALMGREN, L., O. ANDRESEN, A. M. DALIN (2001): Effect of GnRH immunisation on hormonal levels, sexual behaviour, semen quality and testicular morphology in mature stallions. Equine Vet. J. 33, 75-83.

DOI: $10.2746 / 042516401776767340$

MCCOLLUM, W. H., T. V. LITTLE, P. J. TIMONEY, T. W. SWERCZEK (1994): Resistance of castrated male horses to attempted establishment of the carrier state with equine arteritis virus. J. Comp. Pathol. 111, 383-388. DOI: $10.1016 / \mathrm{s} 0021-9975(05) 80096-9$

MCCOLLUM, W. H., T. W. SWERCZEK (1978): Studies of an epizootic of equine viral arteritis in racehorses. J. Equine Med. Surg. 2, 293-299.

MCCOLLUM, W. H., P. J. TIMONEY, J. J. W. LEE, P. L. HABACKER, U. B. R. BALASURIYA, N. J. MACLACHLAN (1999): Features of an outbreak of equine viral arteritis on a breeding farm associated with abortion and fatal interstitial pneumonia in neonatal foals. In: The eight International Conference on Equine Infectious Diseases, Dubai, United Arab Emirates, pp. 559-560.

MISZCZAK, F., L. LEGRAND, U. B. R. BALASURIYA, B. FERRY-ABITBOL, J. ZHANG, A. HANS, G. FORTIER,
S. PRONOST, A. VABRET (2012): Emergence of novel equine arteritis virus (EAV) variants during persistent infection in the stallion: origin of the 2007 French EAV outbreak was linked to an EAV strain present in the semen of a pesistently infected carrier stallion. Virology 423, 165-174. DOI: 10.1016/j.virol.2011.11.028

MISZCZAK, F., S. PRONOST, A. VABRET (2015): Equine viral arteritis : from molecular epidemiology to emergence of pathogenic variants. Virologie 19, 7-18. (in France).

DOI: $10.1684 /$ vir.2015.0588

MISZCZAK, F., K. M. SHUCK, Z. LU, Y. Y. GO, J. ZHANG, S. SELLS, A. VABRET, S. PRONOST, G. FORTIER, P. J. TIMONEY, U. B. BALASURIYA (2011): Evaluation of two magnetic-bead-based viral nucleic acid purification kits and three real-time reverse transcription-PCR reagent systems in two TaqMan assays for equine arteritis virus detection in semen. J. Clin. Microbiol. 49, 3694-3696.

DOI: $10.1128 / \mathrm{jcm} .01187-11$

MORRELL, J. M., R. M. GERAGHTY (2006): Effective removal of equine arteritis virus from stallion semen. Equine Vet. J. 38, 224-229.

DOI: $10.2746 / 042516406776866444$

MORRELL, J. M., P. J. TIMONEY, C. KLEIN, K. SHUCK, J. CAMPOS, M. TROEDSSON (2013): Single-layer centrifugation reduces equine arteritis virus titre in the semen of shedding stallions. Reprod. Domest. Anim. 48, 604-612.

DOI: $10.1111 /$ rda. 12133

NEU, S. M., P. J. TIMONEY, W. H. MCCOLLUM (1987): Persistent infection of the reproductive tract in stallions persistently infected with equine arteritis virus. In: The $5^{\text {th }}$ International Conference on Equine Infectious Diseases, Lexington, pp. 149-154.

RAESIDE, J. I. (1979): Seasonal changes in the concentration of estrogens and testosterone in the plasma of the stallion. Anim. Reprod. Sci. 1, 205-212.

DOI: 10.1016/0378-4320(79)90002-2

ROSER, J. F. (1997): Endocrine basis for testicular function in the stallion. Theriogenology 48, 883-892.

DOI: $10.1016 / \mathrm{s} 0093-691 \times(97) 00309-9$

ROSER, J. F., J. P. HUGHES (1992): Seasonal effects on seminal quality, plasma hormone concentrations, and GnRH-induced LH response in fertile and subfertile stallions. J. Androl. 13, 214-223.

ROTA, A., B. PUDDU, C. SABATINI, D. PANZANI, A. L. LAINE, F. CAMILLO (2018): Reproductive parameters of donkey jacks undergoing puberty. Anim. Reprod. Sci. 192, 119-125.

DOI: 10.1016/j.anireprosci.2018.02.021

SCHULMAN, M. L., A. E. BOTHA, S. B. MUENSCHER, C. H. ANNANDALE, A. J. GUTHRIE, H. J. BERTSCHINGER (2013): Reversibility of the effects of GnRH-vaccination used to suppress reproductive function in mares. Equine Vet. J. 45, 111-113.

DOI: 10.1111/j.2042-3306.2012.00577.x 
SIEME, H., T. CORDES, E. KLUG, H.-O. HOPPEN (2001): Relationship between sexual hormones, seminal characteristics and fertility in stallions. Anim. Reprod. Sci. 68, 351-353

SNIJDER, E. J., J. J. MEULENBERG (1998): The molecular biology of arteriviruses. J. Gen. Virol. 79, 961-979.

DOI: 10.1099/0022-1317-79-5-961

STOUT, T. A. E. (2005): Modulating reproductive activity in stallions: A review. Anim. Reprod. Sci. 89, 93-103. DOI: 10.1016/j.anireprosci.2005.06.015

STOUT, T. A. E., B. COLENBRANDER (2004): Suppressing reproductive activity in horses using $\mathrm{GnRH}$ vaccines, antagonists or agonists. Anim. Reprod. Sci. 82-83, 633-643. DOI: 10.1016/j.anireprosci.2004.04.009

THOMPSON, D. L., JR., R. L. ST GEORGE, L. S. JONES, F. GARZA, JR. (1985): Patterns of secretion of luteinizing hormone, follicle stimulating hormone and testosterone in stallions during the summer and winter. J. Anim. Sci. 60, 741-748.

DOI: $10.2527 / j a s 1985.603741 \mathrm{x}$

TIMONEY, P. J. (1986): Equine viral arteritis: a disease of emerging significance? Equine Vet. J. 18, 166-168.

DOI: 10.1111/j.2042-3306.1986.tb03584.x

TIMONEY, P. J., W. H. MCCOLLUM (1993): Equine viral arteritis. Vet. Clin. North Am. Equine Pract. 9, 295-309.

DOI: $10.1016 /$ s0749-0739(17)30397-8
TIMONEY, P. J., W. H. MCCOLLUM (2000): Equine viral arteritis: further characterization of the carrier state in stallions. J. Reprod. Fertil. Suppl. 56. 3-11.

TIMONEY, P. J., W. H. MCCOLLUM, T. W. MURPHY, A. W. ROBERTS, J. G. WILLARD, G. D. CARSWELL (1987): The carrier state in equine arteritis virus infection in the stallion with specific emphasis on the venereal mode of virus transmission. J. Reprod. Fertil. Suppl. 35, 95-102.

TIMONEY, P. J., W. H. MCCOLLUM, A. W. ROBERTS, T. W. MURPHY (1986): Demonstration of the carrier state in naturally acquired equine arteritis virus infection in the stallion. Res. Vet. Sci. 41, 279-280.

DOI: 10.1016/s0034-5288(18)30616-7

TUKEY, J. W. (1977). Box-and-Whisker Plots, Exploring Data Analysis. Addison-Wesley, Reading, MA. pp. 39-43.

TURKSTRA, J. A., F. J. VAN DER MEER, J. KNAAP, P. J. ROTTIER, K. J. TEERDS, B. COLENBRANDER, R. H. MELOEN (2005): Effects of GnRH immunization in sexually mature pony stallions. Anim. Reprod. Sci. 86, 247-259.

DOI: 10.1016/j.anireprosci.2004.07.010

VIDAMENT, M., B. FERRY, A. L. LAINE, L. WIMEL, F. MISZCZAK, D. BURGER, C. BRIANT, C. DECOURT, A. CARATY (2010) : Daily injection of a GnRH agonist restores the function of reproduction in long-term castrated stallions using anti-GnRH immunization. 36e Journée de la recherche équine, Le Pin au Haras, France, 4 mars 2010, pp. 71-80.

Received: 13 August 2019

Accepted: 11 May 2020

MISZCZAK, F., D. BURGER, B. FERRY, L. LEGRAND, G. FORTIER, A.-L. LAINE, A. VABRET, S. PRONOST, M. VIDAMENT: Anti-GnRH cijepljenje pastuha koji sjemenom izlučuju uzročnika virusnog arteritisa konja - terensko istraživanje. Vet. arhiv 90, 543-556, 2020.

\section{SAŽETAK}

Pastusi su prirodni rezervoar uzročnika virusnog arteritisa konja (EAV), koji se izlučuje u sjemenu, te su zbog toga i potencijalni izvor pojave bolesti. Status prenositelja je ovisan o testosteronu i spontano nestaje u 4 do $40 \%$ pastuha. Izlučivanje testosterona moglo bi se smanjiti anti-GnRH cijepljenjem. $U$ ovom je istraživanju 16 prirodno inficiranih pastuha, koji su izlučivali EAV u sjemenu, cijepljeno dva puta cjepivom Equity ${ }^{\mathrm{TM}}$ te je u nepravilnim razmacima i u terenskim uvjetima praćena količina virusa u sjemenu i koncentracija testosterona u plazmi. Rezultati su prikazani prema mjesecima (M) poslije prvog cijepljenja. Koncentracija testosterona smanjena je s $1,7 \mathrm{na} 0,2 \mathrm{ng} / \mathrm{mL}(\mathrm{P}<0,002)$ poslije tri mjeseca. Poslije pet mjeseci količina virusa smanjena je s 3,2 × 109 na $1,1 \times 106 \mathrm{RNA} \mathrm{kopija/mL} \mathrm{sjemena}$ $(\mathrm{P}<0,001)$. Jedan je pastuh uginuo 7 mjeseci nakon prvog cijepljenja. Od trećeg do desetog mjeseca, 12 od 15 pastuha prestalo je izlučivati virus u sjemenu. Od petog do desetog mjeseca, 9 od 15 pastuha imalo je koncentraciju testosterona u plazmi $\geq 0,5 \mathrm{ng} / \mathrm{mL}$, a njih šestero pokazalo je trajno nisku koncentraciju testosterona $(\leq 0,3 \mathrm{ng} / \mathrm{mL})$. Od 14 pastuha, od kojih se očekivao oporavak reproduktivne aktivnosti u sljedećoj sezoni rasploda $(<\mathrm{M} 12), 8$ je bilo negativno na EAV i dalo ždrijebe, a 6 nije bilo za rasplod (4 zbog reproduktivne deficijencije i 2 jer su bili pozitivni na EAV). Svi su pastusi bili negativni na EAV poslije 22 mjeseca, s tim da je jedan pastuh nakon 15 mjesci treći put cijepljen. Ovi rezultati pokazuju da bi anti-GnRH cijepljenje moglo pomoći u eradikaciji EAV-a u pastuha, bez osobita utjecaja na reproduktivnu sposobnost većine njih, osim što je u nekih smanjeno izlučivanje testosterone dulje potrajalo.

Ključne riječi: pastuh; virusni arteritis konja; anti-GnRH imunizacija; količina virusa; testosteron 